\title{
Analisis Pengelolaan Koin NU Pada Perekonomian Mustahiq Oleh Lazisnu Cabang Nganjuk
}

\author{
Mas'ut $^{1}$, Bhaswarendra Guntur ${ }^{2}$, M. Afif Afdian $\mathrm{Huda}^{3}$ \\ ${ }^{1}$ Institut Agama Islam Pangeran Diponegoro Nganjuk. Jl.Wilis Kramat,Nganjuk. \\ ${ }^{2}$ Institut Agama Islam Pangeran Diponegoro Nganjuk. Jl.Wilis Kramat,Nganjuk. \\ 3Institut Agama Islam Pangeran Diponegoro Nganjuk. Jl.Wilis Kramat,Nganjuk. \\ E-mail: masud.iaipadienganjuk@gmil.com
}

\begin{abstract}
:
Various programs are implemented by LAZISNU to improve community welfare, one of the programs implemented is the KOIN NU Cares Movement program, which is a social movement carried out by Nahdiliyin residents by collecting coins (coins) from residents' homes and grocery stores. The formulation of the problem in this study is how the management of NU coins in LAZISNU Nganjuk branch. How is the classification of Mustahiq at LAZISNU Nganjuk Branch. And how is the distribution of NU Mustahiq Coin at LAZISNU Nganjuk Branch. The purpose of this research is to describe how to manage NU Coin funds at LAZISNU Nganjuk Branch. to find out how LAZISNU classifies Mustahiq. as well as knowing how LAZISNU transfers NU Coin funds to Mustahiq. This research uses a qualitative approach, with the type of case study research, data collection techniques through observation, interviews and documentation. Meanwhile, to analyze the data, the researchers performed data reduction, data display and conclusion drawing. To check the validity of the data, the researcher used the extension of the researcher's participation, the persistence of observation and triangulation. The results showed that the NU coin movement was a social movement carried out by Nahdiliyin residents by collecting change (coins) from the homes of Nahdlatul Ulama residents. This program is a form of follow-up to the Nahdlatul Ulama (PKPNU) activist cadre program. The coins that have been collected in the distributed cans will be taken once a month and put together, then managed to be divided and distributed to mustahiq.

Keywords: Coin Movement, Nahdlatul Ulama', Mustahiq Economy, Lazisnu.
\end{abstract}

\begin{abstract}
:
Beragam program diterapkan LAZISNU untuk meningkatkan kesejahteraan masyarakat, salah satu program yang di jalankan yaitu program Gerakan KOIN NU Peduli, yaitu gerakan sosial yang dilakukan oleh warga Nahdiliyin dengan cara mengumpulkan uang receh (koin) dari rumah-rumah warga dan tempat-tempat toko kelontong. Rumusan masalah pada penelitian ini adalah bagaimana pengelolaan koin NU di LAZISNU cabang Nganjuk. Bagaimana penggolongan Mustahiq di LAZISNU Cabang Nganjuk. Dan bagaimana penyaluran Koin NU Mustahiq di LAZISNU Cabang Nganjuk. Adapun tujuan dari penelitian ini adalah untuk mendeskripsikan cara pengelolaan dana Koin NU di LAZISNU Cabang Nganjuk. untuk mengetahui bagaimana LAZISNU menggolongkan Mustahiq. serta mengetahui bagaimana cara LAZISNU menyalukan dana Koin NU kepada Mustahiq. Penelitian ini menggunakan pendekatan kualitatif, dengan jenis penelitian studi kasus, Teknik pengumpulan data melalui observasi, wawancara dan dokumentasi. Sedangkan untuk menganalisis data peneliti melakukan reduksi data, display data dan penarikan kesimpulan. Untuk pengecekan keabsahan data peneliti menggunakan perpanjangan keikutsertaan peneliti, ketekunan pengamatan dan triangulasi. Hasil penelitian menunjukkan bahwa gerakan koin NU merupakan gerakan sosial yang dilakukan oleh warga Nahdiliyin dengan cara mengumpulkan uang receh (koin) dari rumah warga Nahdlatul Ulama. Program ini sebagai bentuk tindaklanjut dari program kader pergerak Nahdlatul Ulama (PKPNU). Uang receh yang berhasil terkumpul pada kaleng-kaleng yang sudah disebar akan diambil setiap bulan sekali dan dijadikan satu, kemudian dikelola untuk dibagi serta disalurkan pada mustahiq.
\end{abstract}

Kata kunci : Gerakan Koin, Nahdlatul Ulama', Perekeonomian Mustahiq, Lazisnu. 


\section{PENDAHULUAN}

Perkembangan Islam di Indonesia belakangan ini semakin menarik untuk diperhatikan, dimana semakin banyak daerah-daerah yang mulai membiasakan zakat, infaq dan sedekah untuk pemberdayaan kesejahteraan masyarakat. Salah satunya adalah pemberdayaan infaq. Karena infaq memiliki kontribusi yang sangat besar dalam mengatasi kemiskinan yang tengah dihadapi oleh masyarakat. Kata sedekah berasal dari shadaqa atau sidqun yang memiliki arti jujur dan benar. Jadi sedekah yaitu mengeluarkan harta dijalan Allah sebagai bukti kejujuran dan kebenaran iman. Sedekah dalam konsep Islam yaitu sesuatu yang bersifat materiil kepada orang miskin tetapi lebih dari semua itu. Sedekah lebih mencakup semua perbuatan kebaikan baik berupa materi atau non materi

Nahdlatul 'Ulama (NU) ${ }^{1}$ adalah Kebangkitan Cendikiawan Islam dan merupakan sebuah organisasi Islam terbesar di Indonesia. Organisasi ini terdiri pada 31 Januari 1926 dan bergerak di bidang keagamaan, pendidikan, sosial, dan ekonomi. ${ }^{2}$ Kehadiran NU merupakan salah satu cara melembagakan wawasan keagamaan yang dianut jauh sebelumnya, yakni paham Ahlussunnah Wal Jamaah.

Di sisi lain NU dalam meningkatkan kesejahteraan masyarakat mendirikan program NU-CARE Lembaga Amil Zakat Infaq dan Sedekah NU (LAZISNU). ${ }^{3}$ yang merupakan lembaga nirlaba milik perkumpulan NU yang bertujuan, berkhidmat dalam rangka membantu kesejahteraan umat. Mengangkat harkat sosial dengan mendayagunakan dana Zakat, Infaq, Sedekah serta Wakaf. Dan dari berbagai segi program yang di terapkan oleh LAZISNU untuk meningkatkan kesejahteraan masyarakat, salah satu program yang di jalankan oleh LAZISNU yaitu dengan program Gerakan KOIN NU Peduli, yang merupakan gerakan sosial yang dilakukan oleh warga Nahdliyin dengan cara mengumpulkan uang receh (koin) dari rumah-rumah warga dan tempat-tempat toko pracangan.

Pelaksanaan KOIN NU di Kecamatan Nganjuk disambut baik oleh masyarakat, selain untuk menyadarkan warga akan pentingnya berinfak juga dapat sebagai pendidikan bagi anak-anak tentang indahnya berbagi terhadap sesama. Pengelolaan dana infaq di awasi oleh LAZISNU Cabang Nganjuk sebagai badan pengawas UPZISNU.

Dalam pelaksanaan pengumpulan nya tidak ada unsur paksaan di dalamnya melaikan muwafiq dengan sukarela meminta kotak infaq tersebut, yang kemudian dapat di isi oleh seluruh anggota keluarga. Pengumpulan koin dilakukan setiap satu bulan sekali, dengan cara petugas mendatangi rumah-rumah warga yang telah memiliki kotak infaq.

\footnotetext{
${ }^{1}$ Untuk seterusnya Nahdlatul Ulama disingkat NU.

${ }^{2}$ https://map-bms.wikipedia.org/wiki/NahdlatulUlama

${ }^{3}$ Untuk seterusnya Lembaga Amil Zakat Infaq dan Sedekah disingkat LAZISNU.
} 
Pengaruh Koin NU LAZISNU dalam menjalankan program pemberdayaan masyarakat yaitu dengan cara LAZISNU memberikan bantuan dana kepada masyarakat yang ingin membuka usaha, LAZISNU juga memberikan bantuan kepada orang- orang yang kurang mampu, masyarakat yang terkena musibah seperti kebakaran, banjir dan lain-lain yaitu dengan cara LAZISNU memberikan baju, beras, sembako, mukena, sajadah dan barang-barang yang lain yang dimana barang tersebut sangat dibutuhkan oleh keluarga yang terkena musibah tersebut. Dengan adanya program Koin NU pengurus LAZISNU berharap bisa membantu masyarakat menjadi mandiri dan bisa membantu mengurangi angka kemiskinan di Kabupaten Nganjuk yang saat ini dikatakan masih tinggi, terutama pada perempuan, mayoritas pada perempuan yang berumur diatas 50 tahun, karena mereka biasanya sudah tinggal suaminya meninggal sehingga mereka harus berjuang mencari nafkah sendiri untuk menafkahi anak-anaknya.

Berdasarkan paparan di atas, maka peneliti akan melakukan sebuah penelitian dengan judul Analisis Pengelolaan Koin Nu Pada Perekonomian Mustahiq Oleh Lazisnu cabang Nganjuk dengan fokus penelitian Bagaimana pengelolaan Koin NU di LAZISNU cabang Nganjuk, Bagaimana penggolongan Mustahiq di LAZISNU Cabang Nganjuk? dan Bagaimana penyaluran Koin NU Mustahiq di LAZISNU Cabang Nganjuk?. Adapun tujuan dari dilakukannya penelitian ini adalah untuk mendeskripsikan bagaimana dan seperti apa cara pengelolaan dana Koin NU di LAZISNU Cabang Nganjuk. Untuk mengetahui bagaimana LAZISNU menggolongkan Mustahiq. Serta untuk mengetahui bagaimana cara LAZISNU menyalukan dana Koin NU kepada Mustahiq.

\section{METODE PENELITIAN}

Pendekatan dalam penelitian ini adalah menggunakan penelitian kualitatif. Metode penelitian kualitatif, lazimnya data dikumpulkan dengan beberapa teknik pengumpulan data, yaitu: survey, observasi (pemilihan informan), dokumentasi (pengumpulan data). Pada pendekatan ini, peneliti meneliti hasil temuan lapangan berupa laporan terinci dari pandangan responden, dan melakukan studi pada situasi yang alami. Lokasi penelitian adalah tempat dimana penelitian melakukan penelitian guna untuk memenuhi informasi yang di butuhkan sesuai kriteria. Penetapan lokasi penelitian merupakan tahap yang sangat penting dalam penelitian kualitatif, karena dengan ditetapkannya lokasi penelitian berati objek dan tujuan sudah di tetapkan sehingga mempermudah penulis dalam melakukan penelitian. Lokasi ini bisa di wilayah tertentu atau suatu lembaga tertentu dalam masyarakat. Untuk memperoleh data primer di mana data tersebut dari pihak yang bersangkutan yakni, lokasi penelitian di Radio Tasma FM, Perum Griya Riski AS kecamatan Tanjunganom Kabupaten Nganjuk. yang merupakan kantor cabang LAZISNU Kabupaten Nganjuk.

Sumber data dalam penelitian ini adalah seseorang atau lebih yang dipilih sebagai narasumber atau responden. Data primer merupakan data yang diperoleh langsung dari orang-orang atau informan 
yang secara sengaja dipilih sesuai kriteria oleh peneliti untuk memperoleh data-data atau dengan melakukan wawancara yang ada relevansi nya dengan permasalahan penelitian. Data sekunder diperoleh dari dokumen dan artikel, serta media massa yang terkait dengan penelitian ini. Dalam hal ini, peneliti menggunakan data berupa hasil catatan tertulis melalui analisis data dokumen, artikel, media massa dan pengamatan di lokasi penelitian. Dalam penelitian ini yang akan dijadikan sumber data salah satunya adalah subjek yang dijadikan sumber informasi.

Teknik pengumpulan data pada penelitian ini menggunakan beberapa metode, antara lain Survei, Observasi, Wawancara dan Dokumentasi, adapun teknis analisis data pada penelitian ini adalah dengan cara mengelompokkan data ke dalam kategori, menjabarkan ke dalam unit-unit, melakukan sintesa, menyusun ke dalam pola, memilih mana yang penting dan akan dipelajari, dan membuat kesimpulan sehingga mudah dipahami oleh peneliti atau orang lain. Sedangkan Pengecekan keabsahan data dapat dilakukan oleh peneliti sendiri sebagai partisipan, bisa menggunakan data dari hasil wawancara dan juga data yang sudah dikumpulkan (foto, surat, maupun catatan khusus) seperti field note, apakah sesuai hasil wawancara dan hasil pengumpulan datanya. Jika sesuai maka data tersebut dianggap absah seperti memaksimalkan penelitian dengan wawancara dan observasi langsung di lapangan untuk mengumpulkan data. triangulasi sumber dan triangulasi teknik. ${ }^{4}$

\section{HASIL DAN PEMBAHASAN}

\section{Hasil penelitian}

\section{a. Pengertian Pengelolaan}

Pengelolaan adalah proses melakukan kegiatan tertentu dengan menggerakkan tenaga orang lain, proses yang membantu merumuskan kebijaksanaan dan tujuan organisasi proses yang memberikan pengawasan pada semua hal yang terlibat dalam pelaksanaan kebijaksanaan dan pencapaian. Pengelolaan atau manajemen dapat berfungsi dengan baik dengan cara mengikuti alur yang ada mulai dari perencanaan, pengorganisasian, pergerakan dan pengawasan, dimana keempat hal ini membentuk suatu manajemen. ${ }^{5}$

\section{b. Pengelolaan infaq}

Dasar prosedur pengelolaan dana infak adalah memberi rizki, berapa karunia Allah atau menafkahkan hartanya kepada orang lain dengan ikhlas karena Allah. Infak menyerahkan harta atau nilainya dari perorangan atau badan hukum untuk diberikan kepada seseorang karena kebutuhan, mengurangi penderitaan masyarakat, memelihara ketentraman, menghindari hal-hal yang tidak diinginkan.

Pemaparan infak juga dijelaskan di dalam buku Ibnu Taimiyah dengan judul As-Siyasah Asy-Syar'iah, kemudian Ibnu Taimiyah menyebutkan pengalokasian yang dilakukan oleh Umar Bin Khattab ra, "tidak seorang pun yang lebih berhak atas harta itu adalah seorang laki-laki dengan mata pencaharian, orang laki-laki dengan tugasnya, laki-laki dengan ujiannya dan lakilaki dengan kebutuhannya. Umar mengklasifikasikan mereka yang berhak menerima harta infak dalam empat kriteria yaitu:

\footnotetext{
${ }^{4}$ Anis fuad \& Kandung Sapto Nugroho, panduaan Praktis Penelitian Kualitatif, Yogyakarta: Graha ilmu, 2014. 19

${ }^{5}$ Nur Ifan Hamim, Manajemen Pengelolaan hal 21
} 
1) Orang-orang yang kehilangan mata pencaharian yang menjadi tumpuan hidup mereka.

2) Orang-orang yang bertugas mengayomi kaum Muslimin, seperti para pejabat dan ulama, dimana mereka mendatangkan kemaslahatan dunia dan akhirat bagi kaum Muslimin.

3) Orang-orang yang sedang menghadapi ujian, baik yang bertugas menjaga kaum Muslimin dari segala hal yang membahayakan, seperti para Mujtahid baik itu prajurit, penasehat militer atau yang lain.

4) Orang-orang yang benar-benar membutuhkan bantuan.

Infak memiliki ketentuan yang pasti, harus dilaksanakan jika syarat-syarat pengelolaan dana infak tidak jauh sama dengan pengelolaan zakat dan sedekah harus sesuai dengan ketentuan syariat yang harus memiliki syarat-syarat mengelola ZIS yaitu:

1) Beragama Islam

2) Mukallaf

3) Memiliki sifat amanah dan jujur

4) Mengerti dan memahami hukum-hukum mengenai ZIS agar mampu melakukan sosialisasi kepada masyarakat berkaitan dengan ZIS

5) Mampu melaksanakan tugas

Proses penyaluran dana infak harus ditujukan bagi kemaslahatan umat manusia dan tetap dalam koridor berjuang dijalan Allah. Sebagaimana yang telah dituturkan, bahwa agar tercapai sirkulasi kekayaan dan harta, Al-Quran menekankan penggunaan harta itu untuk diberikan kepada orang-orang yang miskin dan fakir, dan orang-orang yang tidak beruntung di dalam masyarakat demi terwujudnya kesejahteraan. ${ }^{6}$

Kewajiban itu harus dilaksanakan sesuai dengan ukuran yang telah ditetapkan dan tidak boleh dikurangi. Sebaliknya, lebih baik jika ditambah. Adapun infak yang belum ada ketentuannya secara pasti maka permasalahannya tergantung pada pribadi selama kondisi masyarakat dan kepentingan umum berjalan sebagaimana biasanya. Infak di bidang ini mempunyai batasan minimum yaitu pemenuhan kebutuhan-kebutuhan syar'i. Adapun batasan maksimum tergantung pada pribadi seseorang Muslimin dan kecintaan nya terhadap kebajikan. Prosedur pengelolaan infak juga diatur di dalam Undang-Undang Pengelolaan Zakat yaitu UU No 23 Tahun 2011 serta Peraturan Pemerintah No. 14 tahun 2014.

\section{c. Pengertian Koin NU}

Koin merupakan gabungan kata dari kotak dan infaq yaitu kotak tempat pengumpulan koin (uang receh) dari rumah-rumah Nahdliyin Program koin NU mandiri adalah salah satu program fundraising NU-care LAZISNU Nganjuk dengan mengumpulkan infak warga sejumlah pecahan koin 100, 200, 500 dan 1000 rupiah serta kaleng sebagai media penyimpanannya.

\section{d. Pengertian Perekonomian}

Perekonomian adalah sistem yang di gunakan oleh suatu negara untuk mengalokasikan sumber daya yang dimilikinya baik kepada individu maupun organisasi di negara tersebut. Adapun perekonomian menurut para ahli:

Menurut Abraham Maslow menyatakan bahwa ekonomi ialah suatu ilmu yang dapat menyelesaikan seluruh permasalahan manusia dalam kehidupan melalui pengelolaan sumber daya yang tersedia. Pengelolaan yang di maksud disini menggunakan teori dan prinsip hingga menempuh jalan yang efisien dan efektif.

\footnotetext{
${ }^{6}$ Mustaq Ahmad, Etika Bisnis dalam Islam. (Jakarta: Pustaka Alkautsar2014) hal 69
} 
Menurut Anwal menyatakan bahwa ekonomi adalah suatu cabang ilmu yang mempelajari tentang cara menentukan keputusan yang efesien dalam penggunaan sumber daya yang tersedia sehingga kebutuhan dan tujuan dari negara, masyarakat maupun individu tercapai.

\section{e. Pengertian Mustahiq}

Mustahik adalah orang-orang yang berhak menerima zakat. Ketentuan tentang siapa saja yang berhak menerima zakat telah diatur dengan jelas dalam QS at-Taubah [9]: 60.8

"Sesungguhnya Zakat itu hanyalah untuk orang-orang fakir, orang miskin, amil zakat, yang dilunakkan hatinya (muallaf), untuk (memerdekakan) hamba sahaya, untuk (membebaskan) orang yang berutang, untuk kepentingan di jalan Allah, dan untuk orang yang sedang dalam perjalanan, sebagai kewajiban dari Allah. Allah Maha Mengetahui, Mahabijaksana.”

Adapun penjelasannya adalah sebagai berikut.

1) Orang fakir, yaitu orang yang penghasilannya tidak cukup untuk memenuhi kebutuhan hidupnya sehari-hari pada taraf yang paling minimal sekalipun.

2) Orang miskin, yaitu orang yang penghasilannya hanya cukup untuk memenuhi kebutuhan hidup (yang pokok) sehari-hari pada taraf yang minimal.

3) Amil zakat, yaitu lembaga atau perorangan yang mengelola zakat.

4) Muallaf, yaitu orang yang baru masuk Islam.

5) Riqab, yaitu untuk memerdekakan hamba sahaya.

6) Gharimin, yaitu untuk membebaskan beban orang yang berutang untuk kepentingan kebaikan.

7) Sabilillah, yaitu untuk kepentingan di jalan Allah.

8) Ibnu Sabil, yaitu orang yang dalam perjalanan yang kehabisan bekal dan perjalanan tersebut untuk tujuan kebaikan, seperti mahasiswa atau santri yang menuntut ilmu di luar kota.

\section{f. Pengertian Manajemen Zakat, Infaq, Sedekah dan Wakaf}

Manajemen zakat di Indonesia berdasarkan pada Undang-Undang No. 38 Tahun 1999 (UU Lama) dan Undang-Undang No. 23 Tahun 2011 (UU Baru) tentang Pengelolaan Zakat. Pengelolaan zakat berdasarkan UU No. 23 tahun 2011 pasal 1 tentang pengelolaan zakat adalah kegiatan perencanaan, pelaksanaan dan pengkoordinasian dalam pengumpulan, pendistribusian dan pendayagunaan zakat. ${ }^{9}$

Badan Amil Zakat Nasional (BAZNAS) merupakan lembaga yang berwenang melakukan tugas pengelolaan zakat secara Nasional. Untuk membantu BAZNAS dalam pelaksanaan pengumpulan, pendistribusian dan pendayagunaan zakat, masyarakat dapat membentuk Lembaga Amil Zakat (LAZ) yang telah mendapat izin Menteri atau pejabat yang ditunjuk oleh Menteri.

Asas pengelolaan zakat menurut Undang- Undang No. 23 Tahun 2011 tentang Pengelolaan zakat adalah:

1) Syariat Islam: Berdasarkan ajaran Islam

2) Amanah: Pengelola zakat harus dapat dipercaya. ${ }^{10}$

\footnotetext{
${ }^{7}$ Anwal, Pengertian Ekonomi.Katagori Belajar Bisnis Pada 24 Mei 2020

${ }^{8} \mathrm{QS}$ at-Taubah [9]: 60

${ }^{9}$ Undang- Undang No. 23 Tahun 2011 tentang Pengelolaan Zakat.

${ }^{10}$ Penjelasan atas Undang- Undang No. 23 Tahun 2011 tentang Pengelolaan Zakat.
} 
3) Kemanfaatan: Pengelolaan zakat dilakukan untuk memberikan kemanfaatan yang sebesar- besarnya bagi mustahik.

4) Keadilan: Pengelolaan zakat dalam pendistribusian nya dilakukan secara adil. ${ }^{11}$

5) Kepastian hukum: Dalam pengelolaan zakat terdapat jaminan kepastian hukum bagi mustahik dan muzaki. ${ }^{12}$

6) Terintegritas: Pengelolaan zakat dilaksanakan secara hierarkis dalam upaya meningkatkan pengumpulan, pendistribusian dan pemberdayaan zakat.

7) Akuntabilitas: Pengelolaan zakat dapat dipertanggungjawabkan dan diakses oleh masyarakat. ${ }^{13}$

Urgensi manajemen zakat adalah menjadi alat untuk membantu mewujudkan tujuan zakat, baik dari sudut pandang muzakki maupun dari sudut pandang mustahik. Dalam hal ini manajemen merupakan alat bantu agar pengelolaan zakat, mulai dari pengumpulan, pendistribusian dan pendayagunaan zakat dapat berjalan secara maksimal. Tanpa manajemen yang baik sebesar apapun potensi zakat tidak akan terkelola dengan baik.

Dalam melaksanakan tugas, Badan Amil Zakat Nasional (BAZNAS) maupun Lembaga Amil Zakat Nasional (LAZNAS) menyelenggarakan fungsi perencanaan, pelaksanaan dan pengendalian dalam pengumpulan, pendistribusian dan pendayagunaan zakat. Serta pelaporan dan pertanggungjawaban pelaksanaan pengelolaan zakat.

Pengukuran efektivitas dapat dilakukan dengan melihat hasil kerja yang dicapai oleh suatu organisasi. Efektivitas dapat diukur melalui berhasil tidaknya suatu organisasi mencapai tujuan-tujuannya. Apabila suatu organisasi berhasil mencapai tujuan, maka organisasi tersebut dikatakan telah berjalan dengan efektif. Hal terpenting adalah efektivitas tidak menyatakan tentang berapa besar biaya yang dikeluarkan untuk mencapai tujuan tersebut. Efektivitas hanya melihat apakah proses program atau kegiatan tersebut telah mencapai tujuan yang telah ditetapkan. ${ }^{14}$

\section{g. Pengelolaan Dana Koin NU Di Lazisnu Untuk Perekonomian Mustahiq Oleh Lazisnu Cabang Nganjuk}

Kotak Koin NU merupakan kotak infaq milik masyarakat Nahdlatul Ulama. Koin merupakan gabungan kata dari kotak dan infaq yaitu sistem pengumpulan koin (uang receh) dari rumah-rumah Nahdliyin yang telah diberikan kotak kecil berwarna hijau (simbol NU). Dalam pelaksanaan pengelolaan Koin NU ini bermula dengan adanya sosialisasi dari pusat MWCNU Nganjuk ke Ranting-ranting (desa) dengan adanya kotak infaq tersebut. Kemudian sosialisasi disalurkan ke warga dengan adanya pengajian Muslimin dan Muslimat. Menurut Bapak Moh. Ilzam mengatakan:

"Di setiap ranting-ranting MWC sudah tersedia kaleng-kaleng koin, yang distok dari cabang lazisnu. Yang kemudian anggota MWC memberikan ke setiap rumah yang ada di setiap ranting kecamatan."15

Pelaksanaan KOIN NU di Kecamatan Nganjuk disambut baik oleh masyarakat, selain untuk menyadarkan warga akan pentingnya berinfak juga dapat sebagai pendidikan bagi anakanak tentang indahnya berbagi terhadap sesama. Pengelolaan dana infaq di awasi oleh LAZISNU Cabang Nganjuk sebagai badan pengawas UPZISNU. Dalam pelaksanaan

\footnotetext{
${ }^{11}$ Ibid., Penjelasan Keadilan

${ }^{12}$ Ibid., Penjelasan Kepastian Hukum

${ }^{13}$ Ibid., Pengertian Akuntabilitas

${ }^{14}$ Ihyaul Ulum, Akuntansi Sektor Publik. 2004 (Malang, UMM Press) hal 294

${ }^{15}$ Wawancara dengan Moh. Ilzam selaku pengurus kantor Lazisnu Cabang Nganjuk, Tanggal 15 Juli 2020.
} 
pengumpulan nya tidak ada unsur paksaan di dalamnya melainkan muwafiq dengan sukarela meminta kotak infaq tersebut, yang kemudian dapat di isi oleh seluruh anggota keluarga. Pengumpulan koin dilakukan setiap satu bulan sekali, dengan cara petugas mendatangi rumahrumah warga yang telah memiliki kotak infaq.

Setelah proses pengumpulan, pengurus ranting dikumpulkan untuk melakukan perhitungan dana yang masuk. Hasil perolehan setiap pengumpulan dilakukan pencatatan per ranting, lalu dari ranting dicatatkan ke MWCNU yang setelah itu dilaporkan ke PCNU. Proses pelaporan dan pencatatan harus bersifat transparan dan terbuka.

Pembagian yang dilakukan oleh pengurus KOIN NU di LAZISNU Cabang Nganjuk sudah sesuai dengan peraturan pusat, dengan membagi dana yang terkumpul setiap bulan kemudian disetorkan ke lembaga yang telah ditentukan. ${ }^{16}$

Gambar 1. Gambaran Bentuk kaleng Koin NU.

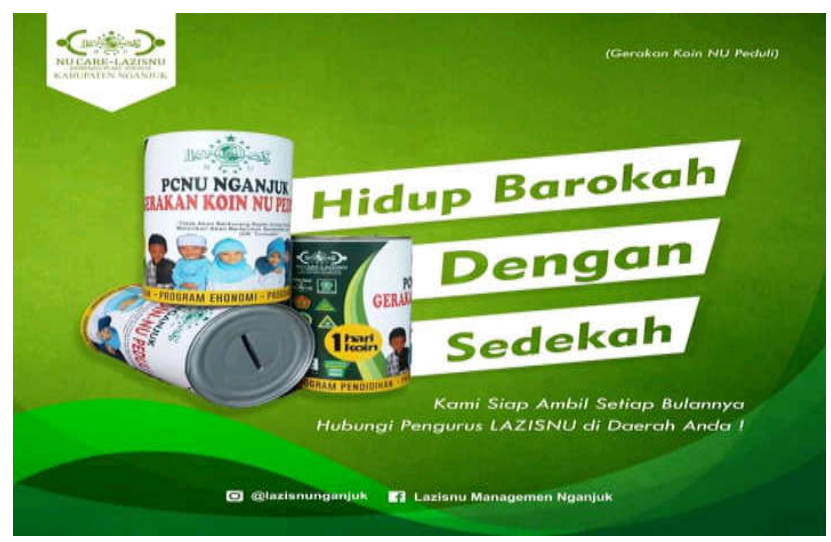

\section{h. Penggolongan Mustahiq Oleh Lazisnu Cabang Nganjuk}

Mustahik adalah istilah atau sebutan bagi orang-orang yang berhak menerima zakat. Zakat sendiri merupakan ibadah yang dilakukan dengan tujuan untuk menyucikan diri, membersihkan harta, dan berbagi kepada orang yang membutuhkan. Perintah zakat termasuk dalam rukun Islam sehingga hukumnya wajib bagi setiap muslim yang memenuhi syarat sesuai syariah.

Zakat terbagi ke dalam dua jenis, yakni Zakat Fitrah dan Zakat Maal. Zakat fitrah adalah zakat yang wajib ditunaikan oleh muslim menjelang Hari Raya Idulfitri. Sementara zakat maal merupakan zakat penghasilan yang didapat dari hasil perkebunan, pertanian, perdagangan, peternakan, ataupun harta temuan. Zakat maal wajib hukumnya bagi orang yang mampu, yakni telah melampaui nisab.

Dibandingkan zakat fitrah, perhitungan zakat maal lebih rumit karena memiliki aturan sendiri. Perhitungan untuk hasil pertanian akan berbeda dengan hitungan untuk emas atau harta temuan.

Mustahik Adalah Golongan yang Berhak Menerima Zakat, Siapa Saja?

1) Penerima zakat, Zakat yang telah dikumpulkan oleh lembaga akan dibagikan kepada orang-orang yang berhak menerimanya. Lantas, siapa saja yang termasuk golongan mustahik? Berikut delapan golongan orang yang berhak menerima zakat.

\footnotetext{
${ }^{16}$ Buku Pedoman Nahdlatul Ulama
} 
2) Fakir, Para fakir termasuk golongan utama yang berhak menerima zakat. Menurut Imam Syafi'i, fakir merupakan orang yang tidak memiliki harta benda atau mata pencaharian. Keadaan ini terjadi secara terus-menerus atau dalam rentang waktu tertentu.

3) Miskin, Berbeda dengan fakir, orang yang termasuk ke dalam kategori miskin adalah orang yang memiliki harta dan pekerjaan, tetapi belum mampu memenuhi kebutuhan hidup sehari-hari.

4) Riqab, atau memerdekakan budak menjadi penerima zakat yang utama. Budak yang dimaksud adalah seorang muslim yang dijadikan budak kemudian dibeli dari harta zakat dan dibebaskan di jalan Allah SWT.

5) Gharim, adalah orang yang memiliki utang dan terdesak mencari pinjaman untuk memenuhi kebutuhan sehari-harinya, baik kepentingan pribadi, sosial, maupun agama. Ada dua jenis gharim. Pertama, gharim limaslahati nafsihi yang terlilit utang demi kepentingan atau kebutuhan pribadi. Kedua, gharim li ishlahi dzatil yang terlilit utang karena mendamaikan manusia, suku, atau qabilah.

6) Mualaf, adalah orang muslim yang imannya masih lemah, tetapi memiliki pengaruh terhadap kaumnya atau sebutan bagi orang yang baru memeluk agama Islam.

7) Fi sabilillah, adalah orang yang berjuang di jalan Allah demi mengharapkan rida. Orang yang masuk dalam golongan ini, baik kaya maupun miskin berhak mendapatkan zakat. Namun perlu dingat bahwa di masa kini jihad fi sabilillah tidak selalu berarti perang. Jihad seorang pelajar harus dilakukan dengan belajar giat untuk mendapatkan rida Allah. Selain itu, fi sabilillah juga bisa berupa organisasi penyiaran dakwah Islam, proyek pembangunan masjid, dan kegiatan lain di jalan Allah SWT.

8) Ibnu Sabil, adalah seorang muslim yang melakukan perjalanan dan memerlukan uang untuk bekal perjalanannya. Orang yang masuk dalam golongan ini berhak menerima zakat sesuai kebutuhannya.

9) Amil Zakat, Jika mustahik adalah orang yang berhak menerima zakat, maka Amil Zakat adalah badan yang dipercaya mengurusi zakat. Amil zakat adalah orang yang telah ditunjuk oleh seorang pemimpin atau wakilnya dan ditugaskan untuk mengumpulkan zakat. Syarat menjadi amil zakat harus merdeka, laki-laki, dan muslim mukalaf. Amil boleh berasal dari orang miskin ataupun kaya. Jika ketujuh golongan sudah menerima haknya, maka amil berhak menerima zakat.

\section{i. $\quad$ Program Penyaluran Koin NU di Lazisnu Cabang Nganjuk}

LAZISNU memiliki program unggulan untuk menciptakan kesejahteraan umat. Di antaranya:

1) NU PRENEUR, Merupakan program program pemberdayaan ekonomi mikro melalui pemberian modal usaha secara bergulir agar tercipta kemandirian usaha.

2) NU SKILL, Merupakan program pembekalan pembekalan ketrampilan untuk anak yatim dan duafa yang putus sekolah yang masih usia produktif sehingga mereka memiliki modal untuk bekerja.

3) NU SMART, Merupakan program layanan mustahiq untuk biaya pendidikan. Program ini dijabarkan melalui program beasiswa siswa yang teladan yang berprestasi yaitu siswa yang paralel di tiap tingkat kelas.

4) NU CARE, Merupakan program tanggap darurat untuk layanan mustahiq bantuan kemanusiaan, dan bantuan hidup program tersebut di wujudkan melalui program renovasi rumah yang sudah roboh. 
Pembahasan

\section{Pengelolaan Dana Koin NU Di Lazisnu Cabang Nganjuk}

Menurut Mustaq Ahmad dalam bukunya yang berjudul Etika Bisnis dalam Islam, ia menjelaskan bahwa dasar prosedur pengelolaan dana infak adalah memberi rizki, berapa karunia Allah atau menafkahkan hartanya kepada orang lain dengan ikhlas karena Allah. Infak menyerahkan harta atau nilainya dari perorangan atau badan hukum untuk diberikan kepada seseorang karena kebutuhan, mengurangi penderitaan masyarakat, memelihara ketentraman, menghindari hal-hal yang tidak diinginkan. ${ }^{17}$

Pelaksanaan koin NU sendiri adalah gerakan membangun kesadaran kolektif bahwa manusia dicipta untuk saling bantu, saling memberi, saling menolong dan saling menguatkan untuk hidup lebih baik. Dalam pedoman pengelolaan Koin NU Lembaga Amil Zakat, Infak dan Sedekah (LAZISNU) Kabupaten, program Koin NU merupakan program fundraising Lembaga Amil Zakat, Infak dan Sedekah (LAZISNU) Cabang Nganjuk dengan tujuan memberdayakan jamaah NU sehingga dapat mandiri dalam pembiayaan kebutuhan dasar warga di bidang kesehatan, ekonomi, dan pendidikan serta menjadi sumber pembiayaan kegiatan NU. Dalam pelaksanaannya, koin NU adalah infak yang diberikan secara ikhlas oleh warga nahdliyin khususnya dan warga Nganjuk umumnya yang disalurkan melalui LAZISNU Cabang Nganjuk untuk ditasyarufkan melalui program LAZISNU agar tepat guna dan tepat sasaran.

Pemaparan infak juga dijelaskan di dalam buku Ibnu Taimiyah dengan judul As-Siyasah Asy-Syar'iah, kemudian Ibnu Taimiyah menyebutkan pengalokasian yang dilakukan oleh Umar Bin Khattab ra, "tidak seorang pun yang lebih berhak atas harta itu adalah seorang laki- laki dengan mata pencaharian, orang laki-laki dengan tugasnya, laki-laki dengan ujiannya dan lakilaki dengan kebutuhannya. Umar mengklasifikasikan mereka yang berhak menerima harta infak dalam empat kriteria yaitu:

1) Orang-orang yang kehilangan mata pencaharian yang menjadi tumpuhan hidup mereka.

2) Orang-orang yang bertugas mengayomi kaum Muslimin, seperti para pejabat dan ulama, dimana mereka mendatangkan kemaslahatan dunia dan akhirat bagi kaum Muslimin.

3) Orang-orang yang sedang menghadapi ujian, baik yang bertugas menjaga kaum Muslimin dari segala hal yang membahayakan, seperti para Mujtahid baik itu prajurit, penasehat militer atau yang lain.

4) Orang-orang yang benar-benar membutuhkan bantuan.

Dalam pengelolaan dana koin NU, LAZISNU Cabang Nganjuk berupaya untuk mengalokasikannya tepat guna dan tepat sasaran. Penyaluran dana program di PRNU dan MWC NU disesuaikan dengan kebutuhan setiap wilayah dan sesuai dengan kreatifitas pengurus dalam melihat kebutuhan masyarakatnya. Adapun program yang menjadi unggulan dari NU CARE LAZISNU Cabang Nganjuk adalah biaya berobat gratis, biaya melahirkan gratis, dan santunan duka. ${ }^{18}$ LAZISNU Cabang Nganjuk sendiri mempunyai program unggulan diantaranya yakni:

1) Layanan kesehatan gratis (LKG), Adalah program yang berfokus pada bantuan biaya berobat dhuafa dan yatim serta penyelenggaraan pengobatan gratis secara berkala.

2) Sekolah Pesantren Maju (SPM), Adalah program yang berfokus pada upaya pemberian bantuan beasiswa yatim atau dhuafa, santri tahfidzul quran, bantuan sarana TPQ, sekolah atau madrasah pelosok desa, pelatihan atau workshop guru.

\footnotetext{
${ }^{17}$ Mustaq Ahmad, Etika Bisnis, hal 69

${ }^{18}$ Pedoman Pengelolaan koin NU Kabupaten Nganjuk
} 
3) Ekonomi Mandiri NU-care (EMN), Adalah program yang berfokus pada pemberian pinjaman modal kerja tanpa bunga bagi wirausahawan dhuafa, bantuan pengembangan produksi dan pemasaran, serta peningkatan kualitas SDM melalui pelatihan usaha.

4) NU-care Siaga Bencana (NSB), adalah program yang berfokus pada bantuan sosial bagi korban bencana baik berupa pemberian donasi keuangan, konsumsi dan kebutuhan primer lainnya.

Dalam membuat keputusan terkait kriteria penerima bantuan, pihak LAZISNU Cabang Nganjuk mempunyai cara untuk menentukan mustahik maupun masyarakat dhuafa melalui rekomendasi langsung dari donatur serta melihat langsung kondisi calon penerima bantuan. Hal ini sesuai dengan kriteria pengalokasian yang dilakukan oleh Umar Bin Khattab ra terkait kriteria yang berhak menerima harta infak yakni orang yang benar-benar membutuhkan dalam buku Ibnu Taimiyah dengan judul As-Siyasah Asy-Syar'iah.

LAZISNU Cabang Nganjuk mempunya dua sifat program berdasarkan pemberian bantuan yakni insidentil dan rutin. Adapun pemberian yang sifatnya insidentil berupa pemberian bantuan kesehatan, bencana dan santunan kaum lansia. Sedangkan yang sifatnya pemberian rutin adalah santunan untuk santri tahfidz setiap bulannya dengan nominal dua ratus lima puluh ribu untuk setiap santri binaan.

Dalam pengelolan dan pendistribusian kaleng koin NU di Cabang Nganjuk terdapat beberapa ketentuan prosentase pembagian hasil perolehan koin kaleng NU antara lain: ${ }^{19}$

$\begin{array}{ll}\text { PCNU } & : 5 \% \\ \text { MWC NU } & : 15 \% \\ \text { PRNU } & : 70 \% \\ \text { UPZIS PRNU/Petugas } & : 10 \%\end{array}$

Selain pengelolaan dan pendistribusian harus ada pencatatan, pencatatan yang dilakukan oleh UPZISNU maupun MWC terkait Undang-undang No 23 Tahun 2011 tentang pengelolaan zakat yang tertera dalam pasal 28 ayat 3 yang berbunyi "pengelolaan infak, sedekah dan dana sosial keagamaan lainnya harus dicatat dalam pembukuan tersendiri". Setelah dilakukan penelitian, administrasi merupakan kekurangan yang harus dibenahi dalam hal pencatatan dan pembukuan. Belum adanya intruksi yang jelas untuk pelaporan hasil penghimpunan untuk setiap UPZISNU maupun MWC yang harus disetorkan kepada Pengurus LAZISNU Cabang Nganjuk, hanya ada beberapa UPZIS maupun MWC yang menyetorkan kepada pengurus cabang LAZISNU Cabang Nganjuk.

Pengelolaan dana koin NU LAZISNU Cabang Nganjuk mempunyai tujuan untuk memberdayakan Jamaah NU sehingga dapat mandiri dalam pembiayaan kebutuhan dasar warga di bidang kesehatan, ekonomi, dan pendidikan; serta mampu menjadi sumber pembiayaan kegiatan NU. Adapun hasil temuan di lapangan, dana koin NU ini menjadi sumber pembiayaan operasional kegiatan NU seperti di UPZIS ranting desa Mojokendil dalam menjalankan program Taman Pembelajaran Al-qur'an (TPQ). Adapun dalam bidang pendidikan sendiri, pengelolaan dana koin NU LAZISNU Cabang Nganjuk memiliki program rutinan pembinaan santri tahfidz setiap bulannya dengan pemberian santunan sejumlah duaratus lima puluh ribu untuk setiap santri binaan. Di bidang ekonomi, pengelolaan dana koin NU LAZISNU Cabang Nganjuk digunakan dalam santunan kaum lansia.

Dalam menganalisis efektivitas pengelolaan dana koin NU dalam meningkatkan kesejahteraan masyarakat yang dilakukan LAZISNU Cabang Nganjuk sebagai berikut:

${ }^{19}$ Pedoman pengelolaan koin NU Cabang Nganjuk 
1) Faktor ketepatan waktu. Pengelolaan dana koin NU LAZISNU Cabang Nganjuk dalam pentasyarufannya, sangat memperhatikan ketepatan waktu dalam pemberian program dan tidak menunda-nunda untuk menahan dana infak. Dalam pengeksekusiannya, sebelum pentasyarufan, pengurus LAZISNU Cabang Nganjuk melakukan koordinasi atau rapat. Setelah rapat besoknya langsung terjun ke lapangan untuk melaksanakan program yang telah dirapatkan. Dalam pentasyarufannya, LAZISNU Cabang Nganjuk mempunya dua sifat program berdasarkan pemberian bantuan yakni insidentil dan rutin. Adapun pemberian yang sifatnya insidentil berupa pemberian bantuan kesehatan, bencana dan santunan kaum lansia. Sedangkan yang sifatnya pemberian rutin adalah santunan untuk santri tahfidz setiap bulannya dengan nominal dua ratus lima puluh ribu untuk setiap santri binaan.

2) Sumber daya manusia yang mengelola program. Dalam pengelolaan program, LAZISNU Cabang Nganjuk mempunyai jobdescription tersendiri yakni manajer pemograman selaku pengelola program-program dari LAZISNU Cabang Nganjuk. dari hasil penelitian yang dilakukan, ada tim tersendiri yang berfokus dalam pengelolaan dana koin NU.. Lembaga amil zakat, infak dan sedekah (LAZISNU) Cabang Nganjuk dalam segi jumlah staff yang dipekerjakan memang masih sangat kurang. Dalam menghimpun dana koin NU belum terorganisir dengan baik serta masing-masing pengurus memiliki kesibukan lain. Akan tetapi para staff ini menjalankan tugasnya sesuai dengan ketentuan yang sudah ditetapkan. Dengan permasalahan yang terjadi tidak menyurutkan semangat LAZISNU Cabang Nganjuk untuk mempunyai tenaga profesional di tengah keterbatasan yang dimiliki.

3) Mengedepankan kerjasama dan komunikasi diantara para tim program. LAZISNU Cabang Nganjuk dalam komunikasi antar tim agar efektivitas pentasyarufan tepat sasaran dan tepat guna mengadakan rapat bulanan dan rapat tiap semester untuk menilai kinerja amil serta program yang sudah dijalankan.

4) Perlunya monitoring program. Dalam proses monitoring, Dalam upaya mencapai efektifitas pengelolaan dana koin NU dalam meningkatkan kesejahteraan masyarakat. LAZISNU Cabang Nganjuk berupaya untuk menjalin kerjasama dengan lembagalembaga di bawah naungan NU lainnya sebagai usaha untuk mengelola dana infak secara tepat guna, contohnya LAZISNU Cabang Nganjuk memiliki program beasiswa prestasi bagi santri tahfidz, maka program tersebut disinergikan dengan Lembaga Pendidikan (LP) Ma'arif, program ekonomi produktif bekerjasama dengan Lembaga Kajian dan Pengembangan Sumberdaya Masyarakat NU (LAKPESDAM).

5) Evaluasi untuk melihat umpan balik (Feed Back Program). LAZISNU Cabang Ngannjuk dalam melihat melihat umpan balik (Feed Back Program) mengadakan rapat rutinan tiap bulan dan semester, hal ini dilakukan untuk mengevaluasi semua kegiatan yang telah berjalan serta mengevaluasi kinerja amil.

Prinsip-prinsip yang menjadi kaidah pokok yang membangun struktur atau kerangka ekonomi Islam yaitu kerja (resource utilization), kompensasi (compensation), efisiensi (efficiency), profesionalisme (professionalism), kecukupan (sufficy), pemerataan kesempatan (equal opportunity), kebebasan (freedom), kerjasama (corporation), persaingan (competition), keseimbangan (equilibrium), solidaritas (solidarity, informasi simetri (synmetric information). ${ }^{2}{ }^{2}$

Sebagai lembaga nirlaba LAZNAS merupakan lembaga zakat milik NU yang bertugas untuk mengelola, menghimpun serta mendistribusikan dana ZIS. Salah satu upaya agar program yang telah direncanakan dapat berjalan dengan baik yakni dengan melakukan penghimpunan (fundraising). Sejauh ini LAZISNU Cabang Nganjuk melakukan penghimpunan melalui program kaleng koin NU (gerakan Nganjuk bersedekah) dengan terjun secara langsung ke

${ }^{20}$ Adiwarman A. Karim, Ekonomi Islam, hal 11-12 
rumah munfiq dan adapula munfiq yang mengantar kaleng koin NU mereka ke lembaga. Dengan penghimpunan kaleng koin NU yang terjun langsung ke rumah munfiq pastinya tidaklah mudah dan mendapatkan kendala selain itu dalam pentasyarufan koin NU ini difokuskan pada empat program yakni layanan kesehatan, ekonomi, pendidikan dan siaga bencana. Dalam hal pentasyarufan pun pasti ada kendala apakah program tersebut efektif dan sesuai dengan tujuan dari LAZISNU yakni lembaga pengelola dana masyarakat (Zakat, Infak, Shadaqah, CSR dan dana sosial lainnya) yang didayagunakan secara amanah dan profesional untuk pemberdayaan umat.

Berikut kendala-kendala internal dalam pengelolaan dana koin NU di LAZISNU Cabang Nganjuk:

1) LAZISNU Cabang Nganjuk dalam melaksanakan penjemputan dana koin NU kurang intens dan belum terjadwal secara rutin sehinga menyebabkan penghimpunan menjadi kurang maksimal, seharusnya pengumpulan dari dana koin NU memiliki jadwal yang terstruktur minimal satu bulan sekali sehingga pengelolaan koin NU lebih optimal.

2) Kurangnya tenaga dalam pengelolaan dana koin NU serta pengurus yang bekerja secara paruh waktu (part time). LAZISNU Cabang Nganjuk lebih banyak melakukan kerjasama dengan lembaga NU lainnya dalam pengelolaan program sehingga hal ini terkesan bahwa lembaga masih belum mampu mengelola program- programnya secara mandiri. Hal ini tidak lain karena kurangnya personel atau tenaga kerja dalam mengelola dana koin NU sehingga terjadi kesulitan saat proses monitoring dalam melihat feedback program yang telah dilaksanakan. Dalam hal ini LAZISNU Cabang Nganjuk harus menambah sumber daya amilin mengingat di dalam lembaga zakat tentunya pengurus memiliki peranan penting dalam menjalankan kegiatan serta tujuan organisasi.

3) Kondisi JPZIS dan UPZIS yang tidak aktif di beberapa daerah juga menjadi kendala pengelolaan dana koin NU ini. UPZIS maupun JPZIS adalah salah satu lembaga pengelola tingkat desa (ranting) serta jaringan-jaringan di bawahnya seperti madrasah, pondok pesantren dan jaringan-jaringan lainnya. LAZISNU MWC maupun UPZIS dan JPZIS memiliki otonom tersendiri untuk mengelola dana koin NU setelah mendapat SK dari Pengurus Cabang. Apabila kondisi UPZIS dan JPZIS yang kurang aktif dalam pengelolaan dana Kalen koin NU ini juga menjadi kendala eksternal yang dihadapi oleh LAZISNU Cabang Nganjuk. Dalam hal ini LAZISNU Cabang Nganjuk harus turun langsung melihat kondisi JPZIS dan UPZIS yang kurang maupun tidak aktif serta memberikan penanganan dan pengarahan agar JPZIS dan UPZIS bisa lebih masif. Nganjuk:

Berikut kendala-kendala internal dalam pengelolaan dana koin NU di LAZISNU Cabang

1) Rendahnya kesadaran masyarakat akan pentingnya bersedekah. Dalam hal ini LAZISNU Cabang Nganjuk harus lebih giat dalam mensosialisasikan program-program dan esensi dari ZIS (zakat, infak dan sedekah).

2) sistem administrasi atau pencatatan yang kurang maksimal dikarenakan hanya beberapa LAZISNU Majelis Wakil Cabang (MWC) maupun UPZIS (unit pengumpul zakat, infak dan sedekah) yang menyetor secara rutin laporan keuangan perolehan dana koin NU kepada LAZISNU Cabang Nganjuk sehingga menyebabkan pengelolaan dana koin NU kurang transparan. Dalam hal ini LAZISNU Cabang Nganjuk seharusnya memberikan instruksi secara berkala kepada setiap LAZISNU Majelis Wakil Cabang (MWC) maupun UPZIS (unit pengumpul zakat, infak dan sedekah) yang menyetorkan laporan keuangannya sehingga pencatatan laporan keuangan menjadi lebih jelas dan transparan. 


\section{Bagaimana Penentuan Mustahiq Oleh Lazisnu Cabang Nganjuk}

Mustahik adalah istilah atau sebutan bagi orang-orang yang berhak menerima zakat. Zakat sendiri merupakan ibadah yang dilakukan dengan tujuan untuk menyucikan diri, membersihkan harta, dan berbagi kepada orang yang membutuhkan. Perintah zakat termasuk dalam rukun Islam sehingga hukumnya wajib bagi setiap muslim yang memenuhi syarat sesuai syariah.

Proses penentuan kriteria mustahik zakat di LAZISNU Cabang Nganjuk dilakukan secara selektif. Sehingga perlu adanya seleksi, pertimbangan, dan penelusuran terhadap calon mustahik zakat yang akan mendapatkan bantuan dana zakat. Penentuan kriteria mustahik zakat dilakukan dengan adil.

Menurut Muh. Ilzam, adil dalam menentukan kriteria mustahik zakat adalah adil yang sesuai dengan kebutuhan mustahik. Karena adil tidak berarti sama rata melainkan sesuai dengan kebutuhan mustahik zakat. Dalam hal pendataan dan pembuktian kebenaran mustahik zakat, mengirimkan tim survey untuk melakukan survey". ${ }^{21}$

Penentuan mustahiq zaka oleh LAZISNU Cabang Nganjuk hasil wawancara dengan Muh Ilzam:

"Calon mustahiq petama-tama di tentukan oleh MWC. Pihak MWC melakukan survey calon mustahiq dan lalu pihak MWC melaporkan ke pihak LAZISNU Cabang Nganjuk, dan cabang menyeleksi kembali apakah benar calon mustahiq termasuk kriteria yang di minta oleh pihak cabang." 22

Survey bertujuan untuk mengetahui keadaan mustahik. Selain itu, survey dilakukan untuk mengetahui kebutuhan yang dibutuhkan oleh mustahik zakat. Hal ini sesuai dengan wawancara yang dilakukan oleh Moh Ilzam.

"Survey ini dilakukan dengan tujuan untuk mengetahui keadaan mustahiknya. Tapi tidak itu saja, survey juga dilakukan untuk mengetahui kebutuhan mustahik"23

Berdasarkan pada kutipan wawancara tersebut, sebelum mustahik tersebut mendapatkan bantuan dana zakat, dari MWC melakukan survey dan melaporkan kepada pihak cabang LAZISNU untuk membuktikan bahwa mustahik tersebut layak mendapatkan bantuan dari dana zakat. Menurut peneliti, hal tersebut harus dilakukan karena kebenaran data dan keberadaan calon mustahik akan terbukti nyata ketika dilakukan survey dilapangan. Begitu juga jenis bantuan yang akan diterima oleh mustahik. Jenis bantuan yang akan diterima oleh mustahik, ditentukan dari hasil survey dan keadaan nyata mustahik. Hal ini dilakukan agar mustahik dapat mendapatkan bantuan sesuai dengan kebutuhan yang dibutuhkannya. Selain form survey kelayakan mustahik yang menentukan calon mustahik tersebut layak mendapatkan bantuan dari LAZISNU Cabang Nganjuk, pendapat masyarakat disekitar calon mustahik juga sangat berpengaruh terhadap keputusan calon mustahik tersebut berhak mendapatkan bantuan atau tidak.

Berdasarkan kutipan wawancara tersebut, LAZISNU Cabang Nganjuk menyatakan bahwa selain skor interval dari form survey kelayakan yang menyatakan calon mustahik layak mendapatkan bantuan.

\section{Penyaluran Koin NU Oleh Lazisnu Cabang Nganjuk}

Pada saat ini penyaluran zakat fitrah, zakat mal ataupun infaq dan shadaqah telah terkoordinasi dengan baik. Penyaluran zakat fitrah tidak hanya dikumpulkan oleh amil zakat

\footnotetext{
${ }^{21}$ Wawancara dengan Muh Ilzam petugas dari kantor LAZISNU Cabang Nganjuk.

${ }^{22}$ Wawancara dengan Muh Ilzam petugas dari kantor LAZISNU Cabang Nganjuk.

${ }^{23}$ Wawancara dengan Muh Ilzam petugas dari kantor LAZISNU Cabang Nganjuk.
} 
untuk kemudian secara langsung disalurkan ke pihak penerima zakat, infaq, dan shadaqah (ZIS), namun dana ZIS yang diterima dikelola untuk pengembangan ekonomi guna meningkatkan kualitas hidup bagi penerima dana ZIS. ${ }^{24}$

Keberadaan Badan Amil Zakat (BAZ) atau Lembaga Amil Zakat (LAZ) saat ini sangat dirasakan manfaatnya oleh masyarakat yang sedang kesusahan. BAZ/LAZ berupaya sedemikian rupa membantu kesulitan masyarakat miskin dengan berbagai programnya. Tak terkecuali program pemberdayaan bagi orang miskin di jalanan. Beragam program dilaksanakan dengan sumber pendanaan dari zakat. Semangat untuk memberikan yang terbaik bagi masyarakat melalui program usaha produktif, terbukti mampu melapangkan beban masyarakat akibat himpitan ekonomi. Hal itu takkan mungkin terjadi tanpa adanya kebaikan dan kesadaran hati para muzakki yang ditopang oleh amil yang profesional, amanah, dan akuntabel. Dalam pengelolaan zakat modern, amil memiliki posisi yang sangat penting dalam mengemas program-program atau produk yang berdayaguna bagi mustahiq (orang yang berhak menerima zakat). Program pemberdayaan zakat tidak hanya bermanfaat bagi mustahiq, tetapi juga bermanfaat bagi muzakki, karena selain dapat menyalurkan zakat, infaq dan shadaqahnya, muzakki juga akan dapat mengikuti pembinaan agama yang dilakukan oleh BAZ ataupun LAZ, baik melalui pengajian rutin yang dilakukan oleh BAZ ataupun LAZ.

\section{KESIMPULAN}

Kompetensi amil dalam mengelola gerakan koin NU peduli yang berjalan di LAZISNU Cabang Nganjuk menggunakan :

Adanya petugas yang tunjuk ditingkat masing-masing (ranting ataupun MWCNU), diutamakan yang sudah mengikuti PKPNU (sistem pengkaderan di NU), Petugas mendapat bisyarah setiap bulannya, Petugas memliki buku induk untuk mencatat pemilik gerakan koin NU Peduli dan perolehannya, hasil gerakan koin NU Peduli tidak boleh dipinjam ataupun dihutang. Para karyawannya untuk mengelola gerakan koin NU peduli dan setiap bulannya diambil setiap rumahrumah Nahdliyin. Sehingga dalam pendistribusian gerakan koin NU peduli setiap tiga bulan sekali agar merata kepada masyarakat miskin. Dalam menjalankan pengelolaan gerakan koin NU peduli sangatlah penting dalam kesejahteraan masyarakat miskin.

Pengelolan yang berjalan di LAZISNU mengunakan metode metode $70 \%$ dikelola oleh ranting, $15 \%$ dikelola oleh MWCNU, 10\% dikelola oleh LAZISNU dan 5\% dikelola oleh PCNU, yang dimana dikerjakan dengan tenaga ahli dalam bidangnya. Sedangkan kendala yang dihadapi dalam mengelola gerakan koin NU Peduli yaitu pengiriman barang yang terlambat, upah petugas yang minim, kemampuan SDM yang kurang dalam pengelolaan uang, modal minim, dan sumber daya pengusaha yang tidak ada.

\section{UCAPAN TERIMA KASIH}

Untuk dapat menyelesaikan penelitian ini, penulis mendapatkan berbagai bantuan dari beberapa pihak. Oleh karena itu penulis berkewajiban menyampaikan rasa terima kasih sedalam-dalamnya, terutama kepada: Rektor Institut Agama Islam Pangeran Diponegoro (IAI PD) Nganjuk yang telah memberikan izin kepada penulis untuk dapat menyelesaikan studi akhir. Dekan Fakultas Syariah dan Ekonomi Islam, yang telah memberikan izin dan pengarahan pada peneliti.

\section{DAFTAR RUJUKAN}

Adiwarman A. Karim, Ekonomi Islam, .

\footnotetext{
${ }^{24}$ Pedoman Teknis Pengelolaan Zakat, Sucipto, 2011:1
} 
Anis fuad \& Kandung Sapto Nugroho, panduaan Praktis Penelitian Kualitatif, Yogyakarta: Graha ilmu, 2014.

Anwal, Pengertian Ekonomi. Katagori Belajar Bisnis Pada 24 Mei 2020.

Buku Pedoman Nahdlatul Ulama

https://map-bms.wikipedia.org/wiki/NahdlatulUlama

Ihyaul Ulum, Akuntansi Sektor Publik. 2004 (Malang, UMM Press) .

Mustaq Ahmad, Etika Bisnis dalam Islam. (Jakarta: Pustaka Alkautsar2014) .

Mustaq Ahmad, Etika Bisnis, .

Nur Ifan Hamim, Manajemen Pengelolaan.

Pedoman pengelolaan koin NU Cabang Nganjuk

Pedoman Pengelolaan koin NU Kabupaten Nganjuk

Pedoman Teknis Pengelolaan Zakat, Sucipto, 2011.

Undang- Undang No. 23 Tahun 2011 tentang Pengelolaan Zakat. 